\title{
Results of the cadaveric kidney transplantations according to national data of turkish organ and tissue information system
}

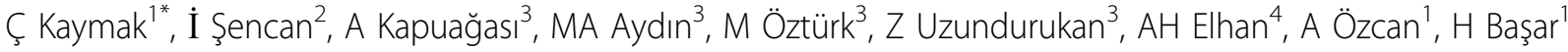 \\ From ESICM LIVES 2015 \\ Berlin, Germany. 3-7 October 2015
}

\begin{abstract}
Introduction
Cadaveric kidney transplantation is performed according to a patient list formed by matching and point score in our country. Demand for renal transplantation can not be met by the number of cadavers introduced to the system because of the increase in number of patients with chronic renal failure who require renal transplantation.
\end{abstract}

\section{Objectives}

We reviewed the results of the patients who had cadaveric kidney transplantation to assess the kidney transplantations in the Turkish Organ and Tissue Information System.

\section{Methods}

The results of the patients who had cadaveric kidney transplantation between years 2011-2014 were reviewed. Patients' age, gender and tissue antigen integration were determined. The chronic rejection and primary graft failure rates were recorded. Survival rates of the grafts and patients during $3,6,9,12,24,36$ ve 48 months were determined. Kaplan-Meier method was used to calculate the survival rates.

\section{Results}

The number of kidney transplantations was 11755 between years 2011-2014 in Turkey. The source of organ in $19.2 \%$ of the transplantations was cadaveric. The mean age of the patients who had cadaveric kidney transplantation was $42.3 \pm 14.4$ (mean \pm SD), and $57.6 \%$ (1301) of the patients were male and $42.4 \%$ (957) were female. Chronic rejection and primary graft failure were

${ }^{1}$ Ankara Training and Research Hospital, Ministry of Health, Department of Anesthesiology and Reanimation, Ankara, Turkey

Full list of author information is available at the end of the article determined in 4.9\% (110) of the patients. Patient and graft follow-up periods were $23.4 \pm 14.9$ (mean \pm SD) months and $22.7 \pm 14.4$ (mean \pm SD) months, respectively. Mean survival time of the patients was $46.81 \pm 0.288$ months, and survival times for $3,6,9,12,24,36$ and 48 months were $\% 95.3 \pm 0.004 ; \% 93.4 \pm 0.005 ; \% 92.4 \pm 0.006$; \%91.8 $\pm 0.006 ; \% 91.4 \pm 0.006 ; \% 91.3 \pm 0.006$ and $\% 91.1 \pm 0.006$, respectively. Mean survival time of the graft was $46.56 \pm$ 0.23 months in these patients and survival times of the graft for 3, 6, 9, 12, 24, 36 and 48 months were $\% 98.1 \pm$ $0.003 ; \% 97.2 \pm 0.004 ; \% 96.3 \pm 0.004 ; \% 96.4 \pm 0.004 ; \% 95 \pm$ 0.005 ; \%94.1 \pm 0.006 and $\% 91.7 \pm 0.013$, respectively.

\section{Conclusions}

Although there are attempts to increase cadaveric donation in the whole world, it is still poor because of the reluctance and irrelevance of the donor families. Even though, the patient and graft survival rates were higher in live kidney transplantations than cadaveric kidney transplantations. In recent decade, cadaver-kidney transplantations also had high success rates. In our opinion, cadaverkidney transplantations should be increased in respect of the results of the cadaver-kidney transplantations in our country.

\section{Authors' details \\ ${ }^{1}$ Ankara Training and Research Hospital, Ministry of Health, Department of Anesthesiology and Reanimation, Ankara, Turkey. ${ }^{2}$ General Directorate of Health Services, Ministry of Health, Ankara, Turkey. ${ }^{3}$ General Directorate of Health Services, Ministry of Health, Organ, Tissue and Transplantation Department, Ankara, Turkey. ${ }^{4}$ Faculty of Medicine, Ankara University, Department of Biostatistics, Ankara, Turkey.}

Published: 1 October 2015 (c) 2015 Kaymak et al.; This is an Open Access article distributed under the terms of the Creative Commons Attribution License (http:// creativecommons.org/licenses/by/4.0), which permits unrestricted use, distribution, and reproduction in any medium, provided the original work is properly cited. 


\section{References}

1. Transplant Proc 2006, 38(2):353-52.

2. Am J Transplant 2009, 9(2):879-93.

doi:10.1186/2197-425X-3-S1-A902

Cite this article as: Kaymak et al.: Results of the cadaveric kidney

transplantations according to national data of turkish organ and tissue

information system. Intensive Care Medicine Experimental 2015 3(Suppl 1):

A902.

\section{Submit your manuscript to a SpringerOpen ${ }^{\circ}$ journal and benefit from:}

- Convenient online submission

- Rigorous peer review

- Immediate publication on acceptance

- Open access: articles freely available online

- High visibility within the field

- Retaining the copyright to your article

Submit your next manuscript at $\gg$ springeropen.com 